\title{
The Effectiveness of Betle Leaf (Piper betle L.) Extract as a Bio- pesticide for Controlled of Houseflies (Musca domestica L.)
}

\author{
Prayudhy Yushananta*(D), Mei Ahyanti (D) \\ Department of Environmental Health, Tanjungkarang Health Polytechnic, Lampung, Indonesia
}

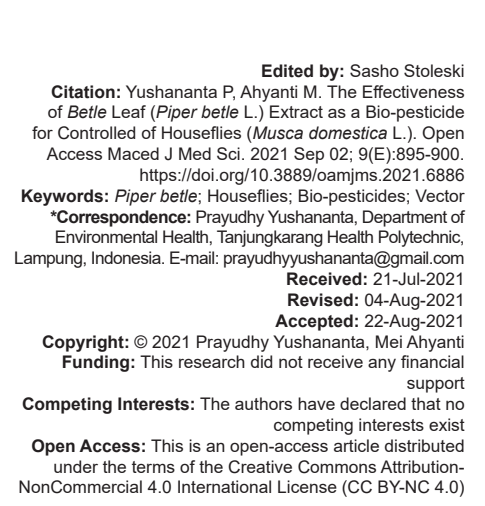

\begin{abstract}
BACKGROUND: The housefly, Musca domestica L., spreads disease by contaminating food. However, chemical insecticides used to combat houseflies can pollute the environment and can harm non-target insects and humans; this demands safer alternatives and pest control options.

AIM: This study aims to evaluate the effectiveness of Piper betle L. leaf extract as a bio-pesticide against houseflies.

METHODS: This study using a factorial design with six variations in concentration $(0 \%, 5 \%, 10 \%, 15 \%, 20 \%$, and $25 \%)$, four variations in contact time $(15,30,60$, and 120 minutes), and 5-day-old M. domestica adults that were bred from residential areas.

RESULTS: The results show that mortality was affected by concentration ( $p$-value $<0.000)$, contact time ( $p$-value $<$ 0.000 ), and the interaction between concentration and contact time ( $p$-value $=0.0007)$. Of the three, concentration had the greatest effect.

CONCLUSION: As such, the use of Piper betle L. extract is a suitable, cheap, and environmentally safe method for controlling M. domestica.
\end{abstract}

\section{Introduction}

Diarrhea is a leading killer of children worldwide, accounting for around $8 \%$ of all deaths among children under 5 years of age. Most of these deaths occur in South Asia and sub-Saharan Africa [1], and in low-income countries [2]. Thus, controlling diarrhea is essential if the world desires to achieve sustainable development goals for child health [3]. In Indonesia, diarrhea affects $11 \%$ of children under 5 and is the second-largest cause of death [4].

Several interventions have been employed to reduce diarrhea: Improvements in water, sanitation, and hygiene facilities; exclusive breastfeeding, adequate complementary feeding, and continued breastfeeding; Vitamin A supplementation; and a preventative rotavirus vaccine [1], [5], [6], [7]. There is strong evidence that flies are vectors of infectious diseases, especially diarrhea [8], [9]. The efficacy of housefly control as prevention for infectious diarrhea in community settings has long been questioned. Vector control can be accomplished by reducing or eliminating breeding sites, reducing housefly attraction sources, and preventing interaction between flies and food, food utensils, people, or disease-causing organisms [3], [6], [10], [11].

The role of houseflies as mechanical vectors for several diarrhea-causing agents is relatively well-established [3], [6], [12], [13], [14], [15]. The housefly, Musca domestica L. (Diptera: Muscidae), is a vector for over 100 serious pathogens, including typhoid, cholera, salmonellosis, shigellosis, dysentery, anthrax, and parasitic worms [3], [16], [17], [18], [19], [20], [21]. Most infectious diarrhea transmission is fecal-to-oral, although the routes taken from feces to ingestion by a host can vary. The main causes of infectious diarrhea are various types of pathogenic bacteria from human feces [22]. M. domestica breeds rapidly and generally settles in human and animal feces, as well as other organic materials such as meat, fruit, and fresh and decayed plant matter [23], [24], [25], [26].

Insecticides are the primary method for controlling houseflies because they are fast, cheap, and convenient. Chemical insecticides such as pyrethroids, organophosphates, and carbamates are used globally. Most of these products no longer exhibit the expected efficacy due to high resistance in pests [16], [17], [18], [27], [28], and the misuse of some insecticides shortens the life of the compounds and pollutes the environment [16], [24], causing harm to non-target insects and humans [23]. Therefore, it is necessary to find plant-based insecticides as an alternative. Bio-insecticides are a group of insecticides derived from plants, such as Pyrethrum, pyrethrin, nicotine, rotenone, limonene, and azadirachtin. The use of bio-insecticides for reducing 
housefly populations is safe for humans and the environment [17], [18], [23], [24], [29], [30].

There are many types of plants in Indonesia that can be used to make natural pesticides. Over 24,000 plant species in 255 families are reported to contain pesticides. Plants with potential as sources of insecticides contain bioactive compounds such as saponins, flavonoids, alkaloids, tannins, and alkenyl phenols [29], [30], [31]. Piper betle L. (Piperaceae) is a native Indonesian vine that can reach a height of $15 \mathrm{~m}$; it contains phenol compounds and phenol derivatives from propenyl, eugenol, carvacrol, chavicol, chavibetol, alylpirokatekol, cavibetol acetate, alylpirokatekol acetate, cineol, estragole, chavibetol methyl ether, p-cymene, caryophyllene, cadin, and cretin. These compounds act as neurotoxins and causes rapid damage and death in insects. These compounds act as neurotoxins and causes rapid damage and death in insects [29], [31], [32], [33]. This study aims to assess the effectiveness of $P$. betle $\mathrm{L}$. leaf extract as a biopesticide for $M$. domestica $\mathrm{L}$.

\section{Materials and Methods}

\section{Ethical considerations}

Ethical considerations were approved by the Health Research Ethics Committee, Tanjungkarang Health Polytechnic, number 162/EC/KEP-TJK.

\section{Study design and setting}

This study utilized a factorial design with two replication experiments, six levels of concentration (5\%, $10 \%, 15 \%, 20 \%$, and $25 \%$, with $0 \%$ as a control), and four levels of contact time (15 min, $30 \mathrm{~min}, 60 \mathrm{~min}$, and $120 \mathrm{~min}$ ). The research subjects were 5 -day-old $M$. domestica L. bred from residential areas, with ten flies per treatment.

\section{M. domestica $L$.}

The study was conducted at the Entomology Laboratory in the Department of Environmental Health, Tanjungkarang Health Polytechnic. Cages that were $45 \mathrm{~cm} \times 47 \mathrm{~cm} \times 47 \mathrm{~cm}$ were used for rearing the houseflies used in the study. The cages were covered with mesh gauze and had sleeves on the front and back. A researcher used their forearm to introduce a milk solution, a sugar solution, and an oviposition tray. A cotton pad soaked in a 3\% sugar solution was placed in each cage to provide sugar and water. Adult food consisted of $50 \%$ glucose and $50 \%$ MacConkey broth powder. Sugar solutions and food were provided every day. Cotton pads soaked in fresh milk were provided to flies for 3 days, in order to increase egg production. After 3 days, the flies were given a solution of milk and sugar. For larval rearing, a sterilized wheat bran mixture (38 g), milk powder $(2 \mathrm{~g})$, and $60 \mathrm{ml}$ of water were used as described by Pavela [17], Zahoor et al. [30].

The cage for rearing flies was purchased from PD Karya Mitra Usaha, Indonesia. Glucose, and MacConkey broth from MERCK production. Sugar and fresh milk are bought from the market.

\section{P. betle $L$}

$P$. betle L. leaves were obtained from traditional markets in Bandar Lampung City and then identified by the Department of Biology at Lampung University. The plants were cleaned using distilled water, and then dried in the shade for 15 days. Crushed, dried plants were placed in a dry-oven at $60^{\circ} \mathrm{C}$ for $20 \mathrm{~min}$. For extraction, $100 \mathrm{~g}$ of the sample was mixed with $300 \mathrm{ml}$ of ethanol, and then the mixture was subjected to a rotary shaker for $24 \mathrm{~h}$ at $220 \mathrm{rpm}$. The mixture was filtered using Whatman filter paper. The filtrate was stored in a sterilized, gray, airtight glass bottle and stored in a refrigerator at $40^{\circ} \mathrm{C}$ for later use. Concentrations (5\%, 10\%, 15\%, 20\%, and $25 \%$ ) were prepared from the stock solution using distilled water as a solvent. Procedures were similar to those described previously [17], [29], [30], [32].

Waring (Model No. $8010 \mathrm{BU}$ ) used to crushed $P$. betle L. leaves, and drying used a Dry-oven (Model No. 01034250001100) from WTB Binder, Germany. Stirring for extraction with a Rotary Shacker (Model No SG-400W-2019A) from Oshiyama, Japan, and evaporated with a water bath (Model No DIN128763-K1) produced by Memmert, Germany. All materials were weighed with Analytical balance (Model No. ITA1904375) from Bel Engineering, Italy.

\section{Bioassay}

The test bottles used were $250 \mathrm{~mL}$ glass bottles with a surface area of $180 \mathrm{~cm}^{2}$ (Model No 100-21801365, from Duran, Malaysia). Each glass bottle was sprayed with $1 \mathrm{~mL}$ of a bio-pesticide solution with the correct concentration (5\%, 10\%, 15\%, 20\%, or $25 \%$ ). The insecticide stuck evenly to the entire surface of the bottle and bottle cap; the glass bottle was rotated multiple times. The bottle was left open for $1 \mathrm{~h}$ afterward so that the bio-pesticide could dry completely. The sample bottles for the control were prepared in the same manner, but distilled water was used instead of a bio-pesticide solvent [34], [35].

A total of 10 adult houseflies (aged 5 days) derived from rearing were put into each insecticide glass bottle for a specified amount of time (15 min, $30 \mathrm{~min}, 60 \mathrm{~min}$, or $120 \mathrm{~min}$ ). For the control, ten flies were treated with distilled water. After exposure, the houseflies were transferred to the cages $(25 \mathrm{~cm} \times$ 
$25 \mathrm{~cm} \times 25 \mathrm{~cm}$ ) and left for $24 \mathrm{~h}$. The flies were given a $50 \%$ sugar water solution or liquid milk; the cage was placed in a room with a temperature of $27-30^{\circ} \mathrm{C}$ and a humidity of $60-80 \%$.

\section{Statistical analysis}

Data were analyzed to determine the individual and combined effects of the research variables (concentration and contact time) used a two-way analysis of variance (ANOVA). Tukey's test determines the individual means, which are significantly different from a set of means. To interpreting the strength association used Omega square, following Cohen's guidelines $\left(\omega^{2}=0.01\right.$ is a small association, $\omega^{2}=0.06$ is medium, and $\omega^{2}=0.14$ is strong). All analyzed using SAS 9.4 software.

\section{Results}

\section{Model}

The ANOVA test found an F-value of 44.40 and $p<0.0001$, indicating the significance of the model (Table 1). The $\mathrm{R}^{2}$ value was $97.70 \%$, meaning that $97.70 \%$ of the diversity in the data for concentration, contact time, and $M$. domestica mortality could be explained by the model.

Table 1: Statistical analysis by two-way ANOVA

\begin{tabular}{llllllll}
\hline Source & DF & $\begin{array}{l}\text { Mean } \\
\text { Square }\end{array}$ & F-value & Pr $>$ F & $\begin{array}{l}\text { Omega } \\
\text { Square }\end{array}$ & $\begin{array}{l}\text { Effect } \\
\text { Size }\end{array}$ & $\begin{array}{l}\text { Power } \\
\text { of Test }\end{array}$ \\
\hline Model & 23 & 16.648 & 44.4 & $<0.0001$ & & & \\
Concentration & 5 & 65.783 & 175.42 & $<0.0001$ & 0.431 & 0.870 & 1.000 \\
Contact time & 3 & 9.805 & 26.15 & $<0.0001$ & 0.061 & 0.256 & 1.000 \\
Concentration $\times$ Contact time & 15 & 1.638 & 4.37 & 0.0007 & 0.042 & 0.209 & 0.996 \\
R Square & 0.9770 & & & & & \\
\hline ANOVA: Analysis of variance. & & & & & &
\end{tabular}

The partial omega squared value was calculated to determine the strength of the relationships among concentration, contact time, and number of deaths [36]. The results show that the relationship between concentration and number of deaths, ignoring contact time and the interaction of concentration and contact time, was strong $\left(\omega^{2}>0.14\right)$. The relationship between contact time and number of deaths, ignoring concentration and the interaction between contact time and concentration, was moderate $\left(\omega^{2}>0.06\right)$. The relationship between the number of deaths and the interaction of concentration and contact time, ignoring concentration and contact time, was weak $\left(\omega^{2}>0.01\right)$.

Effect size was calculated to determine the effect of treatment [36]. Concentration had a significant effect on the model (effect size > 0.40). Contact time had a moderate effect (effect size $>0.25$ ), and the interaction between contact time and concentration had a weak effect (effect size > 0.01). The power of the test for the three variables approached 1.00 , meaning that the probability of getting significant results was close to 100\% (Table 1).

\section{Mortality by extract concentration}

In this study, testing was conducted to determine the effect of $P$. betle $L$. leaf extract concentration on the mortality of $M$. domestica. Six concentrations were used: $5 \%, 10 \%, 15 \%, 20 \%, 25 \%$, and $0 \%$ (Figure 1).

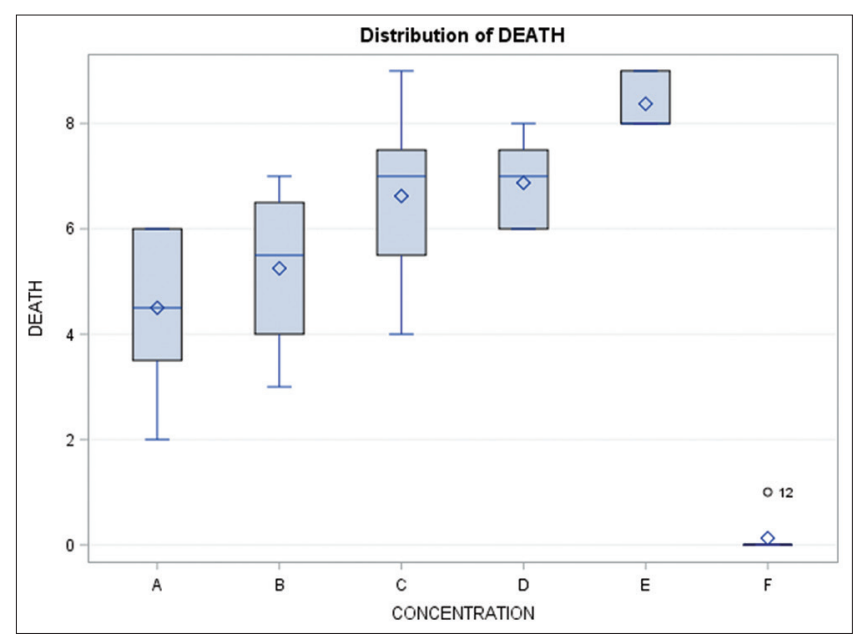

Figure 1: Musca domestica mortality by concentration (\%)

In Figure 1, the highest mortality was at an extract concentration of $25 \%$, with as many as 8.37 flies dead $(\mathrm{SD}=0.51)$; the lowest mortality was at a concentration of $5 \%$, with as many as 4.50 flies dead (SD = 1.51). In the control, the death rate was $0.12(S D=0.35)$. The number of deaths at a concentration of $15 \%$ was equal to the number of deaths at a concentration of $25 \%$, but there was a wider distribution of data.

Statistical analysis found an F-value of 175.42 and $p<0.0001$. As such, concentration influences the number of $M$. domestica deaths (Table 1). Overall, differences in mortality occurred among all groups, except between $5 \%$ and $10 \%$ and between $15 \%, 20 \%$ and 20\% (Table 2).

Table 2: Turkey test results for concentration

\begin{tabular}{llllll}
\hline Concentration (\%) & 5 & 10 & 15 & 20 & 25 \\
\hline 5 & - & 1.000 & $0.031^{*}$ & $0.005^{*}$ & $0.000^{*}$ \\
10 & 1.000 & - & 0.155 & $0.031^{*}$ & $0.000^{*}$ \\
15 & $0.031^{*}$ & 0.155 & - & 1.000 & 0.092 \\
20 & $0.005^{*}$ & $0.031^{*}$ & 1.000 & - & 0.411 \\
25 & $0.000^{*}$ & $0.000^{*}$ & 0.092 & 0.411 & - \\
\hline${ }^{*}$ Significant. & & & & &
\end{tabular}

\section{Death by contact time}

Tests were carried out to determine the effect of contact time on the death of $M$. domestica; there were four durations: 15, 30, 60, and $120 \mathrm{~min}$ (Figure 2). The results showed that the highest mortality (6.16 flies, $\mathrm{SD}=3.06)$ was at $20 \mathrm{~min}$ of contact, and the lowest (4.08 flies, $S D=2.71$ ) was at 15 min of contact. At 15 min of contact, the deaths were very widely distributed.

Statistical analysis found an F-value of 26.15 and a $p<0.0001$, demonstrating that the number of 


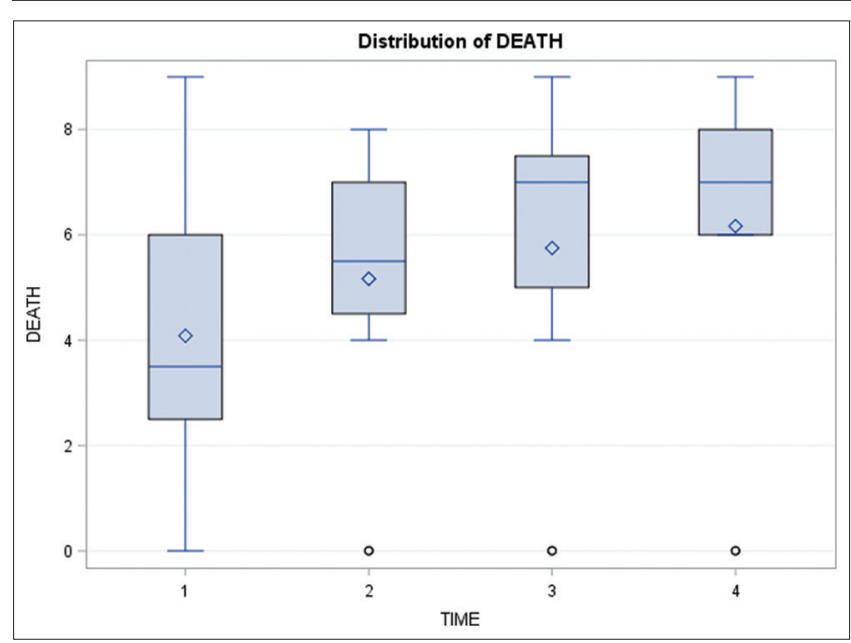

Figure 2: Musca domestica mortality by contact time (min)

deaths is influenced by contact time (Table 1). In general, there were no differences in mortality at contact times between 30 and $60 \mathrm{~min}$, and between 60 and $120 \mathrm{~min}$ (Table 3).

Table 3: Turkey test results for contact time

\begin{tabular}{lllll}
\hline Contac Time $(\mathrm{min})$ & 15 & 30 & 60 & 120 \\
\hline 15 & - & 0.366 & $0.021^{*}$ & $0.009^{*}$ \\
30 & 0.366 & - & 1.000 & 0.873 \\
60 & $0.021^{*}$ & 1.000 & - & 1.000 \\
120 & $0.009^{*}$ & 0.873 & 1.000 & - \\
\hline${ }^{*}$ Significant. & & & &
\end{tabular}

\section{Mortality by concentration and contact}

\section{time}

Statistical analysis found an F-value of 4.37 and a $p<0.0007$, indicating that the number of deaths is impacted by concentration and contact time (Table 1). For all contact durations, the highest mortality was at a concentration of $25 \%$; the lowest mortality was at a concentration of $5 \%$. In addition, for all concentration, the highest mortality was at a contact time of 120 min; and the lowest mortality was at a concentration of contact time of $5 \mathrm{~min}$. In the control, there were no deaths at 30,60 , or 120 min of contact time (Figure 3).

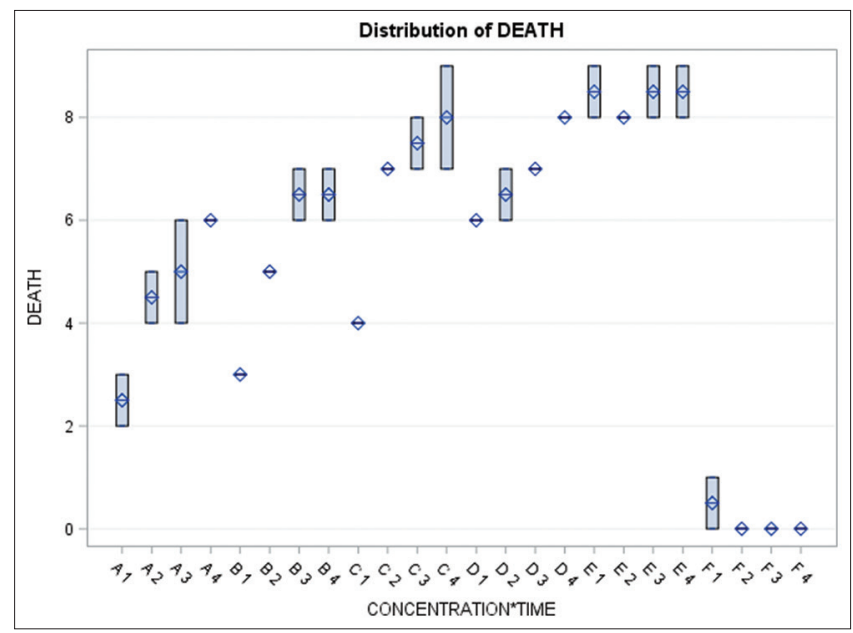

Figure 3: Musca domestica mortality by concentration and contact time

\section{Discussion}

The previous studies have shown that $P$. betle L. leaf extract has insecticidal properties that could potentially be exploited for pest eradication. Although such research used quantified extracts, the extracts were tested on larvae. Anisah's research [29] has particular relevance because it clearly shows that $P$. betle L. leaf extract mostly contains tannins, flavonoids, and eugenol chavicol, which are effective against $M$. domestica. The results presented here align with previous studies and provide further evidence of the benefits of $P$. betle $L$. leaf extract for controlling adult M. domestica.

There were significant differences between the subject groups and the control (Figure 3). At 60 min of exposure, the $5 \%$ extract caused a mortality rate of over $50 \%$. With 15 min of exposure, the $25 \%$ extract led to an $80 \%$ mortality rate. For each duration of contact, higher concentrations of extract led to higher mortality rates. These results confirm previous research [17], [29], [31].

The most abundant compounds in $P$. betle $\mathrm{L}$. leaves are tannins [29]. Tannins can block muscles' response to skin cell walls and inhibit enzyme and substrate activity, which can cause digestive disorders and damage cell walls; tannins act as a contact poison and stomach poison [29], [30], [31], [32], [37], [38]. Pesticides enter the fly's body, shrinking its body tissue and killing it. Flies' habit of licking, which is related to the shape and structure of their mouths, is a way for tannins to enter the fly's digestion. Flavonoid compounds can affect the respiratory and nervous systems. Flavonoid compounds enter flies' bodies through the respiratory tract and attack the central nervous system, which can cause paralysis and muscle rupture, leading to death [29]. In this experiment, after being exposed, the flies were placed in a cage with continuously monitored temperature and humidity. The cage used was made in such a way that air could enter the cage freely, allowing the flies to breathe. The increase in fly mortality indicates that the compounds in green betle leaves work to inhibit the respiratory system.

Other compounds in $P$. betle $\mathrm{L}$. leaves that can also kill flies are eugenol and chavicol. These two compounds have antiseptic properties but are synergistic as pesticides, especially larvicides [29], [39], [40]

Green $P$. betle L. leaf extract contains contact toxins and respiratory toxins; exposure to the extract can reduce appetite, inhibit egg-laying, and inhibit growth [17], [30], [37]. The bioactive compounds in extracts from biological materials that are used as pesticides can affect the muscular system, nervous system, respiratory system, hormonal balance, reproduction, and antifeedants, leading to death [41]. Studies have shown that prolonged exposure to each concentration increases fly mortality, likely because the 
length of exposure allows more active compounds to enter the flies' bodies [23], [29].

\section{Conclusion}

Overall, this study supports using $P$. betle L. and its main components (tannins, flavonoids, eugenol, and chavicol) to control housefly populations; $P$. betle $L$. leaf extract demonstrated remarkable efficacy against adult $M$. domestica. Thus, $P$. betle $\mathrm{L}$. is suitable for use as a cheap and environmentally safe alternative for controlling $M$. domestica. However, further research into the toxicological effects for non-target insects is urgently needed.

\section{Author Contributions}

All the authors contributed equally to the preparation, development, and completion of this manuscript.

\section{Ethics}

This article is original and contains unpublished material. The corresponding author confirms that the other authors have read and approved the manuscript and that there were no ethical issues involved.

\section{References}

1. UNICEF. Diarrhoea. UNICEF; 2020. Available from: https:// data.unicef.org/topic/child-health/diarrhoeal-disease. [Last accessed on 2021 Jan 26].

2. Walker CL, Rudan I, Liu L, Nair H, Theodoratou E, Bhutta ZA, et al. Global burden of childhood pneumonia and diarrhoea. Lancet. 2013;381(9875):1405-16. http://doi.org/10.1016/ S0140-6736(13)60222-6 PMid:23582727

3. Das JK, Hadi YB, Salam RA, Hoda M, Lassi ZS, Bhutta ZA. Fly control to prevent diarrhoea in children. Cochrane Database Syst Rev. 2018;12(12):CD011654. http://doi.org/10.1002/14651858. CD011654.pub2 PMid:30556598

4. Ministry of Health Indonesia. Indonesia Health Profile 2019. Vol. 53. Indonesia: Ministry of Health Indonesia; 2019. p. 1689-99.

5. Bhutta ZA, Das JK, Walker N, Rizvi A, Campbell H, Rudan I, et al. Interventions to address deaths from childhood pneumonia and diarrhoea equitably: What works and at what cost? Lancet. 381(9875):1417-29. http://doi.org/10.1016/ S0140-6736(13)60648-0

PMid:23582723

6. Yushananta P, Usman S. The incidence of diarrhea in babies affected through the cleanliness of eating utensils and hands. J Med Sci Clin Res. 2018;6(9):137. https://dx.doi.org/10.18535/ jmscr/v6i9.137

7. Yushananta $\mathrm{P}$, Ahyanti M, Hasan A. Community based total sanitation in Muara Putih Village, Natar District, Pesawaran Regency. Sakai Sambayan. 2021;2(2):76. https://dx.doi. org/10.20473/jkl.v13i2.2021.113-120

8. Emerson PM, Lindsay SW, Walraven GE, Faal H, Bøgh C Lowe $\mathrm{K}$, et al. Effect of fly control on trachoma and diar rhoea. Lancet. 1999;353(9162):1401-3. https://dx.doi.org/10.1016/ S0140-6736(98)09158-2

PMid:10227221

9. Agtini MD. Diarrhea Morbidity and Mortality in Toddlers in Indonesia 2000-2007. Vol. 2. Ministry of Health; 2009. p. 26-32.

10. Chavasse DC, Blumenthal U, Kolsky P. Fly control in prevention of diarrhoeal disease. Lancet. 1994;344(8931):1231. https:// dx.doi.org/10.1016/s0140-6736(94)90547-9 PMid:7934565

11. Pickering AJ, Ercumen A, Arnold BF, Kwong LH, Parvez SM, Alam $\mathrm{M}$, et al. Fecal indicator bacteria along multiple environmental transmission pathways (water, hands, food, soil, flies) and subsequent child diarrhea in Rural Bangladesh. Environ Sci Technol. 2018;52(14):7928-36. https://dx.doi. org/10.1021/acs.est.8b00928

PMid:29902374

12. Chavasse D, Shier R, Murphy O, Huttly S, Cousens S, Akhtar T. Impact of fly control on childhood diarrhoea in Pakistan: community-randomised trial. Lancet. 1999;353(9146):22-5.

13. Muñoz DJ, Rodríguez R. Bacterial and parasite agents in adult housefly Musca domestica collected in el peñón, Sucre State, Venezuela. [Agentes bacterianos y parasitarios en adultos de la mosca común musca domestica recolectadas en el peñón, estado Sucre, Venezuela]. Rev Cient Facult Cienc Vet Univ Zulia. 2015;25(2):159-66.

14. Diclaro JW $2^{\text {nd }}$, Cohnstaedt LW, Pereira RM, Allan SA, Koehler PG. Behavioral and physiological response of musca domestica to colored visual targets. J Med Entomol. 2012;49(1):94-100. https://doi.org/10.1603/ME10257

15. Chaiphongpachara $\mathrm{T}$, Laojun $\mathrm{S}$. Using the modern morphometric approach to determine sexual dimorphism of three medically important flies (Order: Diptera) in Thailand. Biodivers J Biol Divers. 2019;20(5):542. https://doi.org/10.13057/BIODIV/ D200542

16. Wang JN, Hou J, Wu YY, Guo S, Liu QM, Li TQ, et al. Resistance of house fly, Musca domestica L. (Diptera: Muscidae), to five insecticides in Zhejiang Province, China: The Situation in 2017. Can J Infect Dis Med Microbiol. 2019;2019:4851914. https://doi. org/10.1155/2019/4851914

17. Pavela R. Insecticidal properties of several essential oils on the house fly (Musca domestica L.). Phytother Res. 2008;22(2):2748. https://doi.org/10.1002/ptr.2300

18. Pavela R, Maggi F, Petrelli R, Cappellacci L, Buccioni M, Palmieri A, et al. Outstanding insecticidal activity and sublethal effects of Carlina acaulis root essential oil on the housefly, Musca domestica, with insights on its toxicity on human cells. Food Chem Toxicol. 2020;136:111037. https://doi.org/10.1016/j. fct.2019.111037

19. JunqueiraAC, Ratan $A, A c e r b i E$, Drautz-Moses DI, Premkrishnan BN, Costea PI, et al. The microbiomes of blowflies and houseflies as bacterial transmission reservoirs. Sci Rep. 2017;7(1):16324. 
https://doi.org/10.1038/s41598-017-16353-x.

20. Tan SW, Yap KL, Lee HL. Mechanical transport of rotavirus by the legs and wings of Musca domestica (Diptera: Muscidae). J Med Entomol. 34(5):527-31. https://doi.org/10.1093/ jmedent/34.5.527

PMid:9379457

21. Onyenwe E, Okore OO, Ubiaru PC, Abel C. Housefly-borne helminth parasites of Mouau and its public health implication for the university community. Anim Res Int. 2016;13(1):2352-8.

22. Collinet-Adler S, Babji S, Francis M, Kattula D, Premkumar PS, Sarkar R, et al. Environmental factors associated with high fly densities and diarrhea in Vellore, India. Appl Environ Microbiol. 2015;81(17):6053-8. https://doi.org/10.1128/AEM.01236-15 PMid:26116684

23. Geden CJ. Status of biopesticides for control of house flies. J Biopestic. 2012;5:1-11.

24. Klauck V, Pazinato R, Volpato A, da Silva dos Santos D, Santos RC, Baldissera MD, et al. Insecticidal effect of several essential oils against Musca domestica. Comp Clin Pathol. 2008;27(1):167-72.

25. Chaiphongpachara $T$, Laojun $S$, Jongvisuttisan $N$, Tubsamut $P$, Dasom A. A checklist of medically important flies (Order: Diptera) in the central region of Thailand. Biodivers $\mathrm{J}$ Biol Divers. 2018;19(6):2134-9.

26. Chaiphongpachara T, Tubsamut P. Geometric morphometry of pupae to identify four medically important flies (Order: Diptera) in Thailand. Biodivers J Biol Divers. 2019;20(6):200603.

27. NielsenAA, Skovgård $H$, Stockmarr A, Handberg KJ, Jørgensen PH. Persistence of low-pathogenic avian influenza H5N7 and H7N1 subtypes in house flies (Diptera: Muscidae). J Med Entomol. 2011;48(3):608-14. https://doi.org/10.1603/me11017 PMid:21661322

28. Farooq M, Freed S. Infectivity of housefly, Musca domestica (Diptera: Muscidae) to different entomopathogenic fungi. Braz J Microbiol. 2016;47(4):807-16. https://doi.org/10.1016/j. bjm.2016.06.002 PMid:27522925

29. Anisah A, Sukesi TW. Effectiveness of sirih leaf extract (Piper betle L.) as a house fly larvae (Musca domestica) larvicidal. J Disease Vektor. 2018;12(1):39-46. https://doi.org/10.22435/ vektorp.v12i1.283

30. Attaullah, Zahoor MK, Zahoor MA, Mubarik MS, Rizvi H, Majeed $\mathrm{HN}$, et al. Insecticidal, biological and biochemical response of Musca domestica (Diptera: Muscidae) to some indigenous weed plant extracts. Saudi J Biol Sci. 2020;27(1):10616. https://doi.org/10.1016/j.sjbs.2019.05.009

PMid:31889824
31. Adibah A, Dharmana E. Larvicidal effectiveness test of boiled betle leaf (Piper betle L.) against aedes aegypti larvae gainst aedes value of Lc50, Lt50, and the rate of larvae mortality. Diponegoro Med J. 2019;6(2):244-52.

32. Putu N, Kusuma R, Muderawan IW. Chemical Content Analysis of Green Betle Leave (Piper betle) Extract with GC-MS. In: MIPA National Seminar 2016, Ganesha Education University; 2016.

33. Prakash B, Shukla R, Singh P, Kumar A, Mishra PK, Dubey NK. Efficacy of chemically characterized Piper betle L. essential oil against fungal and aflatoxin contamination of some edible commodities and its antioxidant activity. Int $\mathrm{J}$ Food Microbiol. 2010;142(1-2):114-9. https://doi.org/10.1016/j. ijfoodmicro.2010.06.011

PMid:20621374

34. Brogdon WG, Chan A. Guideline for Evaluating Insecticide Resistance in Vectors Using the CDC Bottle Bioassay. Centers for Disease Control and Prevention. Atlanta: Centers for Disease Control and Prevention; 2020. p. 1-28.

35. McAllister JC, Scott M. CONUS Manual for Evaluating Insecticide Resistance in Mosquitoes Using the CDC Bottle Bioassay Kit. Atlanta: Centers for Disease Control and Prevention; 2020. p. 1-19.

36. Cohen J. Statistical Power Analysis for the Behavioral Sciences. $2^{\text {nd }}$ ed. New York: Lawrence Erlbaum Associates; 1988.

37. Armianty A, Mattulada IK. Antibacterial effectiveness of betel leaf extract (Piper bet/e Linn) to Enterococcus faecalis. J Dentomaxillofac Sci. 2014;13(1):17.

38. dos Santos Dias L, de Macoris ML, Andrighetti MT, Otrera VC, Dias AD, Bauzer LG, et al. Toxicity of spinosad to temephosresistant Aedes aegypti populations in Brazil. PLoS One. 2017;12(3):e0173689. https://doi.org/10.1371/journal. pone. 0173689 PMid:28301568

39. Row LC, Ho JC. The antimicrobial activity, mosquito larvicidal activity, antioxidant property and tyrosinase inhibition of Piper betle. J Chin Chem Soc. 2009;56(3):653-8.

40. Mansbridge J. Skin substitutes to enhance wound healing Expert Opin Investig Drugs. 1998;7(5):803-9. https://doi org/10.1517/13543784.7.5.803

PMid:15991970

41. Dwipayana M, Wijaya I, Sritamin M. The effectiveness test of extracts of betel leaf (Piper betle L.), Kirinyuh (Chromoloena odorata) and Tembelekan (Lantana camara L.) against the population of root knot nematodes (Meloidogyne Spp.) and plant growth of chili (Capsicum annuum L.). E-J Agro Trop. 1985;6(1):62-71. 